\title{
Interaction of Silicic Acid with Poly(1-vinylimidazole)
}

\author{
V. V. ANNENKOV, E. N. DANILOVTSEVA, E. A. FILINA, Y. V. LIKHOSHWAY \\ Limnological Institute, Siberian Branch, Russian Academy of Sciences, P.O. Box 4199, Irkutsk 664033, Russia
}

Received 3 July 2005; accepted 10 October 2005

DOI: 10.1002 / pola.21190

Published online in Wiley InterScience (www.interscience.wiley.com).

\begin{abstract}
Poly(1-vinylimidazole) reacts with silicic acid and poly(silicic acid), giving rise to water-soluble complexes and insoluble composites because of hydrogen bonding. The composition, structure, and morphology of the obtained products have been studied with elemental analysis, Fourier transform infrared spectroscopy, and scanning electron microscopy. The main direction of the reaction depends not only on the initial ratio of the components, concentration, and $\mathrm{pH}$ but also on the sequence of the reagent mixing: the presence of poly(1-vinylimidazole) macromolecules during the formation of silicic acid stabilizes soluble complexes, which precipitate with an excess of $\mathrm{H}_{4} \mathrm{SiO}_{4}$ only. These soluble complexes may serve as a pattern of particles responsible for the transport of silicic acid in diatom algae and other organisms that assimilate silicon from the environment. (C) 2005 Wiley Periodicals, Inc. J Polym Sci Part A: Polym Chem 44: 820-827, 2006
\end{abstract}

Keywords: biomineralization; electron microscopy; nanocomposites; silicas; watersoluble polymers

\section{INTRODUCTION}

Interactions between inorganic polymeric hydroxides and organic macromolecules have been intensively studied recently in the following areas:

- The synthesis of materials with developed surfaces. ${ }^{1-8}$

- The design of composite materials, including systems with the mixing of components on a molecular level (nanocomposites). ${ }^{9-22}$

- Basic research of biomineralization. ${ }^{23-40}$

A great number of publications deal with silicon-containing systems as silicon is the second most widespread element on Earth, its compounds are easily available, and the resulting

Correspondence to: V. V. Annenkov (E-mail: annenkov@ lin.irk.ru)

Journal of Polymer Science: Part A: Polymer Chemistry, Vol. 44, 820-827 (2006) (ㄷ) 2005 Wiley Periodicals, Inc. materials are valuable for electronics, solidphase organic synthesis, chromatography, and so forth. Silicon alkoxides are the most popular precursors for the synthesis of polysiloxane structure $^{1-5,7,10-12,15,41}$ because they allow to be involved in the reaction a lot of commercial polymers that are soluble in organic solvents. The interaction of water-soluble polymers with poly (silicic acid) (PSA) is less studied despite the evident advantage of synthesis in a water medium with inexpensive inorganic silicates. Such reactions are also important for understanding silicon assimilation from the environment by living organisms (diatoms, sponges, and others). The main studies in this area are related to the research of the structure and morphology of the finished composites from previously prepared PSA sols. ${ }^{42-48}$ Investigations concerning the initial stages of the reaction with monomeric silicic acid giving rise to primary soluble complexes are few in number. ${ }^{49-54}$

We used poly(1-vinylimidazole) (PVI) as the subject of study in this article. This polymer is a 


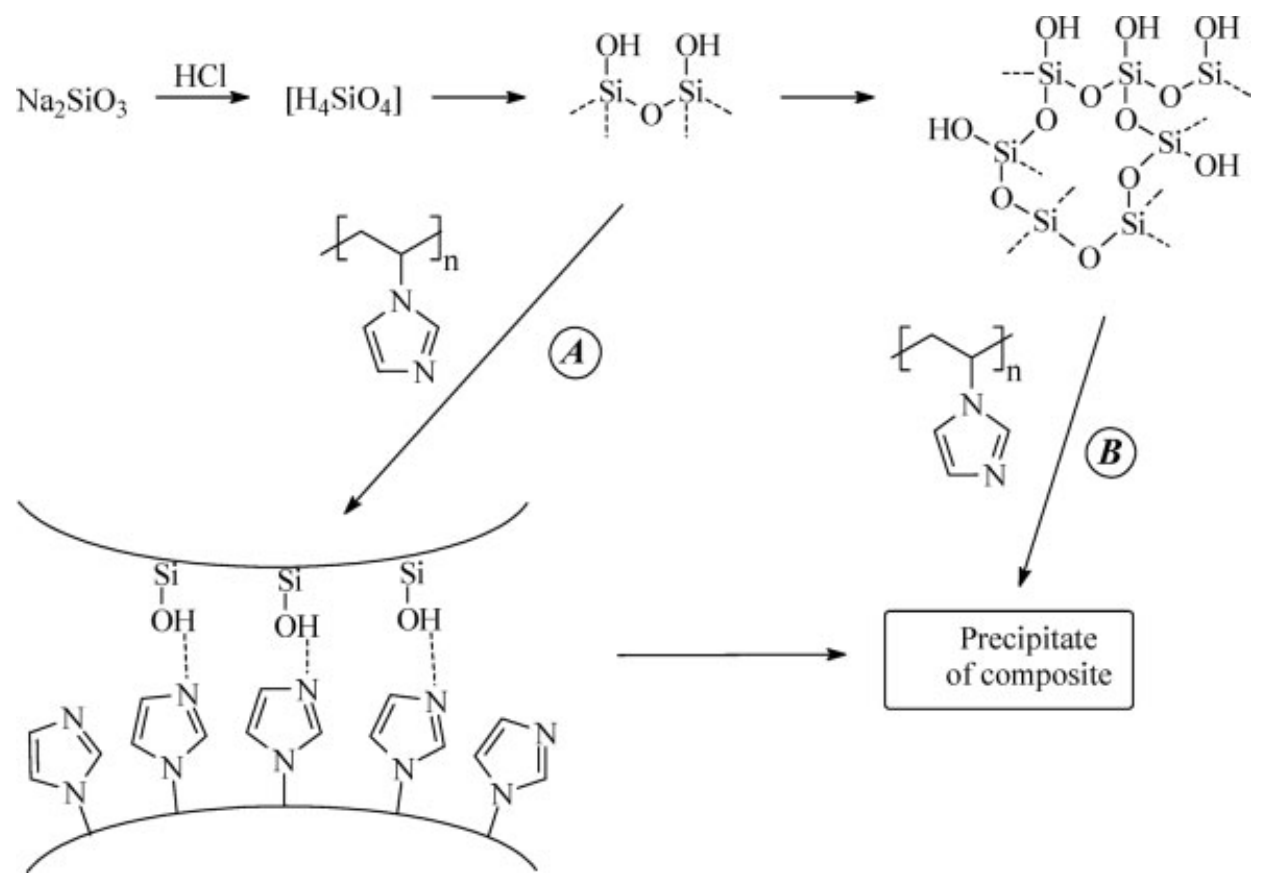

Figure 1. Possible ways of PVI interaction with silicic acid and products of its condensation.

weak base $\left(\mathrm{p} K_{\mathrm{BH}+}=5-6^{55}\right)$. Its peculiar features in comparison with aliphatic amines are negligible protonation within the neutral $\mathrm{pH}$ range and a high capacity for hydrogen bonding. ${ }^{56,57} \mathrm{At}$ the same time, imidazole structures are widely spread in nature. 1-Vinylimidazole and its polymers have been produced on a commercial scale since the 1960s. Silicic acid was generated by the neutralization of sodium silicate $\left(\mathrm{Na}_{2} \mathrm{SiO}_{3}\right)$, which allowed us to study two routes of the reaction: the complexation of the previously obtained PSA with PVI and the formation of silicic acid in the presence of PVI with possible competitive condensation reactions in the solution and on the matrix of the organic polymer.

\section{EXPERIMENTAL}

PVI (molecular mass $=160,000$ ) was obtained according to ref. 58 by the radical polymerization of the monomer in benzene. $\mathrm{Na}_{2} \mathrm{SiO}_{3} \cdot 9 \mathrm{H}_{2} \mathrm{O}$ was recrystallized from water before use. ${ }^{59}$

Potentiometric measurements were performed on a Multitest ionometer with a combined $\mathrm{pH}$ electrode in a temperature-controlled cell at 20 $\pm 0.02{ }^{\circ} \mathrm{C}$. Fourier transform infrared (FTIR) spectra were recorded on a Bruker IFS25 spec- trometer ( $\mathrm{KBr}$ pellets). Quantum chemical calculations were accomplished by the PM3 method within the framework of the unrestricted Hartree-Fock method with the Hyper-Chem 3.0 program with full optimization of geometry. Samples for scanning electron microscopy (SEM) were placed on stubs cooled with liquid nitrogen, dried in vacuo, and coated with gold in a SDC 004 (Balzers). SEM analysis was performed with a Philips SEM 525M.

\section{RESULTS AND DISCUSSION}

The neutralization of alkali metal silicates with strong acids in a water medium causes the rapid formation of oligomeric PSA particles. ${ }^{60}$ After the introduction of PVI into this system, complexes of two types may be formed (Fig. 1). Relatively short PSA chains can react with PVI, forming soluble interpolymeric complexes (route A), which are converted into a composite precipitate with the further condensation of silanol groups. On the other hand, the reaction of larger and branched PSA oligomers with PVI must cause directly insoluble products (route B).

Indeed, the addition of solutions obtained by the acidification of $0.035 \mathrm{M} \mathrm{Na}_{2} \mathrm{SiO}_{3}$ with hydro- 


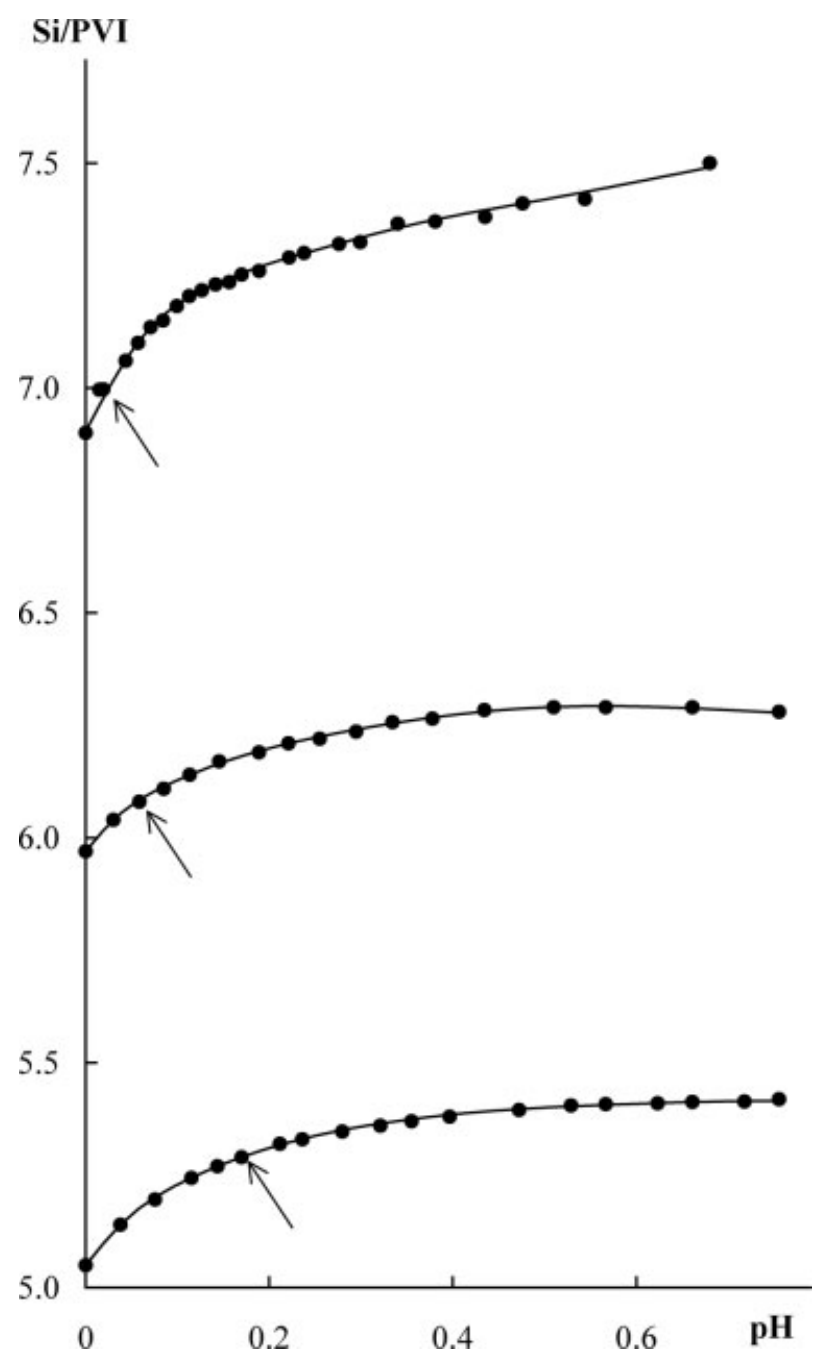

Figure 2. Changes in the $\mathrm{pH}$ upon the addition of $\mathrm{Na}_{2} \mathrm{SiO}_{3}(0.035 \mathrm{M})$ to a PVI solution $(0.01 \mathrm{M})$. The $\mathrm{pH}$ values of the initial solutions were equalized by $1 \mathrm{M}$ $\mathrm{HCl}$. The precipitation points are marked with arrows.

chloric acid to $0.01 \mathrm{M}$ PVI of the same $\mathrm{pH}$ gives rise to a precipitate (Fig. 2) with PSA concentrations of $2-17 \%$, depending on the $\mathrm{pH}$ of the mixed solutions. The further titration of PVI with PSA solutions is accompanied by an increase in the $\mathrm{pH}$ and amount of the precipitate. The $\mathrm{pH}$ increase is likely due to the condensation of silanol groups under the action of the PVI matrix:
These reactions must provide the elimination of alkali or a concentration decrease of acidic silanol groups, depending on the $\mathrm{pH}$. The formation of hydrogen bonds with imidazole moieties also suppresses the dissociation of PSA and may lead to the observed increase in $\mathrm{pH}$ as in the case with poly(acrylic acid). ${ }^{56,57}$

In contrast to the system with preliminary neutralized $\mathrm{Na}_{2} \mathrm{SiO}_{3}$, the titration of its mixture with PVI is homogeneous even with a $15 \%$ excess of silicate, and only at a high PVI concentration $(0.05 \mathrm{M})$ is it possible to obtain a precipitate during a day of storage (Table 1). Such facts seem to be unusual as PVI readily forms insoluble complexes with linear polymeric acids. ${ }^{56,57}$ In the case of PSA, additional crosslinking by a polysiloxane net is expected. An increase in the $\mathrm{Na}_{2} \mathrm{SiO}_{3}$ concentration in the mixture up to a $40 \%$ excess results in a precipitate at $\mathrm{pH} 8$ that dissolves below $\mathrm{pH} 4$.

PVI is a relatively weak base, and its titration curve in water does not have an inflection at the neutralization point [Fig. 3(a), curve 1]. Titration curves of PVI- $\mathrm{Na}_{2} \mathrm{SiO}_{3}$ mixtures lie above the PVI curve, having an additional inflection point that is more visible as a minimum in differential curves [Fig. 3(b)]. The dependence between the position of these additional inflection points and the component ratio [Fig. 3(c)] tends to be limited at Si/PVI $=0.6$. This indicates an increase in the basicity of some PVI units under complexing with PSA. The possible mechanism of additional stabilization of protonated azole cycles includes hydrogen bonding with silanol oxygen [Fig. 4(b)]. Quantum chemical calculations show that the formation energy of the isomeric structure is $19 \mathrm{kcal} / \mathrm{mol}$ higher without this hydrogen bond [Fig. 4(a)]. The proposed structure is in agreement with titration data [Fig. 3(c)], which indicate an increase in the basicity during the complexing of approximately half of the PVI units. The partial protonation of the organic polymer also causes a $\mathrm{pH}$ increase and the aforementioned anomalous solubility of PVI-PSA complexes upon the addition of PSA to PVI solutions. The activity of siloxane

$$
\begin{aligned}
& { }_{-}^{-} \mathrm{Si}-\mathrm{O}^{-}+\mathrm{HO}-\mathrm{Si}=\longrightarrow \underset{\mathrm{Z} i-\mathrm{O}-\mathrm{Si}=}{-}+\mathrm{OH}^{-} \\
& \underset{\mathrm{Z} i}{-}-\mathrm{OH}+\mathrm{HO}-\mathrm{Si}=\longrightarrow \mathrm{Si}-\mathrm{O}-\mathrm{Si}=+\mathrm{H}_{2} \mathrm{O}
\end{aligned}
$$


Table 1. Synthesis of Composites from $\mathrm{Na}_{2} \mathrm{SiO}_{3}$ and $\mathrm{PVI}^{\mathrm{a}}$

\begin{tabular}{|c|c|c|c|c|c|c|}
\hline \multirow[b]{2}{*}{ No. } & \multirow{2}{*}{$\begin{array}{l}\text { Si/PVI Units in } \\
\text { the Initial Mixture }\end{array}$} & \multirow[b]{2}{*}{$\mathrm{pH}$} & \multicolumn{3}{|c|}{ Precipitate Composition (\%) } & \multirow{2}{*}{$\begin{array}{l}\text { Si/PVI Units in } \\
\text { the Composite }\end{array}$} \\
\hline & & & $\mathrm{N}$ & $\mathrm{Si}$ & $\mathrm{C}$ & \\
\hline \multicolumn{7}{|c|}{ Addition of PSA to the PVI solution } \\
\hline 1 & 0.37 & 7.35 & 16.89 & 15.8 & 37.9 & 0.93 \\
\hline 2 & 0.95 & 7.90 & 13.90 & 21.78 & 29.4 & 1.56 \\
\hline 3 & 1.43 & 8.09 & 11.38 & 22.64 & 26.3 & 1.98 \\
\hline \multicolumn{7}{|c|}{ Neutralization of the $\mathrm{Na}_{2} \mathrm{SiO}_{3}-\mathrm{PVI}$ mixture with $\mathrm{HCl}$} \\
\hline 4 & 1.0 & 6.65 & 13.4 & 18.3 & 29.7 & 1.36 \\
\hline 5 & 1.0 & 6.60 & 13.8 & 17.3 & 29.2 & 1.25 \\
\hline 6 & 1.0 & 5.9 & 15.0 & 15.7 & 32.7 & 1.04 \\
\hline 7 & 1.0 & 4.18 & 12.1 & 20.6 & 24.6 & 1.70 \\
\hline 8 & 1.143 & 6.87 & 17.1 & 16.1 & 35.9 & 0.94 \\
\hline 9 & 1.43 & 6.70 & 17.2 & 15.9 & 38.3 & 0.92 \\
\hline 10 & 2.86 & 6.96 & 9.9 & 26.9 & 21.6 & 2.71 \\
\hline
\end{tabular}

${ }^{\mathrm{a}}$ Initial PVI concentration $=0.01$ (runs 1-3 and 8-10) or $0.05 \mathrm{M}$ (runs 4-7); concentration of $\mathrm{Na}_{2} \mathrm{SiO}_{3}$ (or PSA) $=0.03$ (runs 1-3 and 8-10) or $0.05 \mathrm{M}$ (runs 3-7); $\mathrm{HCl}$ concentration for neutralization = 1 (runs 1-7) or $0.1 \mathrm{M}$ (runs 8-10).

oxygen in hydrogen bonding was mentioned earlier. $^{61,62}$

Of particular interest is the ability of PVI to give soluble complexes with PSA at a neutral $\mathrm{pH}$ as a model of one of the stages of the biosili- fication process. In the case of diatoms, soluble forms of PSA as a complex with biopolymers are supposed to explain silica transfer from the cell membrane to the growing valve. ${ }^{63}$ Polymeric amines and highly basic proteins isolated from

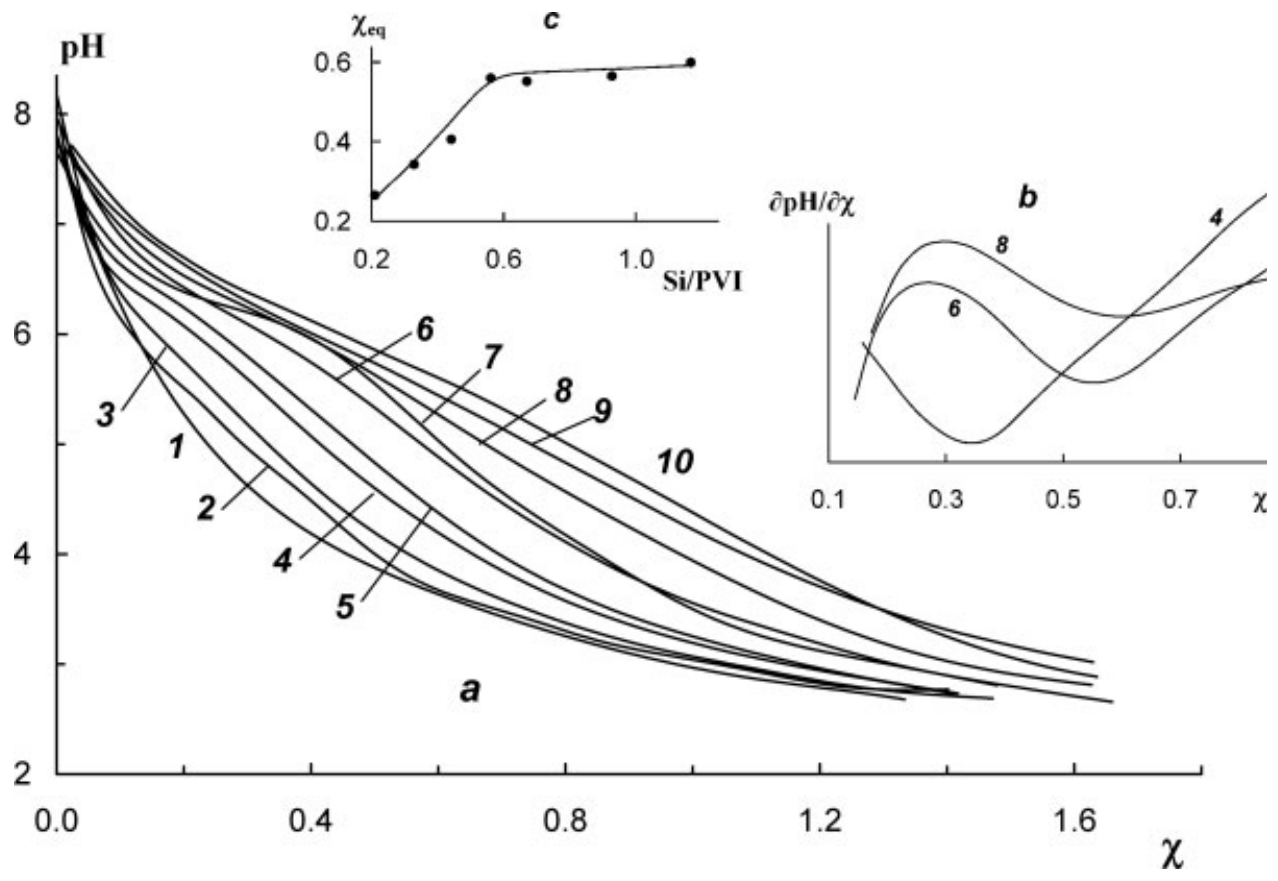

Figure 3. $\mathrm{pH}$ versus $[\chi=\mathrm{HCl}] /[\mathrm{PVI}$ units $]$ at titration of $\mathrm{PVI}-\mathrm{Na}_{2} \mathrm{SiO}_{3}$ mixture after neutralization point of sodium silicate (a), differential curves (b) and dependence of inflection points $\left(\chi_{\text {eq }}\right)$ on Si/PVI ratio (c). Initial Si/PVI ratio: $0(\boldsymbol{1}), 0.075(\boldsymbol{2})$, $0.10(3), 0.33(4), 0.44(5), 0.67(6), 0.93(7), 1.17(8), 1.42(9), 1.13$ in $0.1 \mathrm{M} \mathrm{NaCl}$ (10). Starting PVI concentration was $0.0075 \mathrm{M}$. $0.1 \mathrm{M} \mathrm{HCl}$ was used as titrant. 


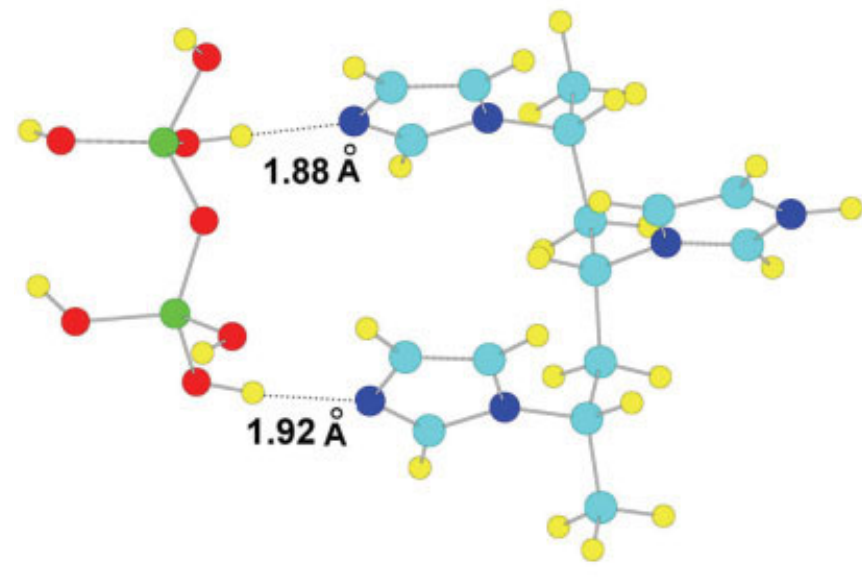

a

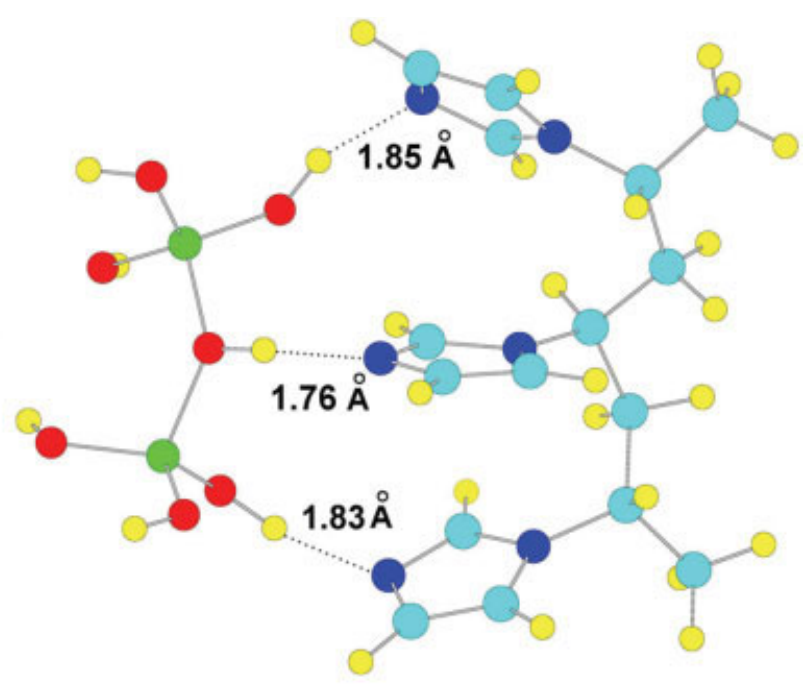

b

Figure 4. Optimized model structures of PVI-PSA protonated complexes.

diatom cell walls ${ }^{29,31,35,39,40}$ may serve as transporters of silicic acid coming through the cell membrane in a monomeric form and condensing by mechanism A (Fig. 1). It is also known ${ }^{64}$ that the $\mathrm{pH}$ value is decreased to 5 in the growing valve, and this causes the weakening of the PSA complex with biopolymers and results in PSA condensation on existing silica particles.

Table 1 contains data on the composition of PVI-PSA precipitates obtained from both previously neutralized $\mathrm{Na}_{2} \mathrm{SiO}_{3}$ and a PVI- $\mathrm{Na}_{2} \mathrm{SiO}_{3}$ mixture. Precipitates formed with a PVI excess have a nearly equimolar ratio of azole units and silicon, whereas with a excess of silicate or PSA, it is possible to obtain products enriched with silica. Evidently, only particles with completely bonded PVI units are insoluble, and excessive silicon-containing component can embed into products by the creation of three-dimensional polysiloxane nets.

IR spectra of PVI, solid PSA, and a 1:1 PVIPSA composite are shown in Figure 5. The PVI spectrum contains bands of stretching vibrations of imidazole cycles $(1500,1406,1286$, and 1228 $\left.\mathrm{cm}^{-1}\right)$, stretching vibrations of azole $\mathrm{C}-\mathrm{H}(1110$ and $1082 \mathrm{~cm}^{-1}$ ), and bending vibrations of heterocycles $\left(917,827\right.$, and $\left.744 \mathrm{~cm}^{-1}\right){ }^{65}$ The PSA spectrum also agrees with literature data: ${ }^{66}$ bands at 1082 (with a shoulder at $1200 \mathrm{~cm}^{-1}$ ) and $800 \mathrm{~cm}^{-1}$ correspond to $\mathrm{Si}-\mathrm{O}$ stretching motions, adsorption at $470 \mathrm{~cm}^{-1}$ can be attributed to a bending $\mathrm{Si}-\mathrm{O}-\mathrm{Si}$ mode, and vibrations of the $\mathrm{Si}-\mathrm{OH}$ bond are observed at 960 $\mathrm{cm}^{-1}$. In the case of the PVI-PSA composite, azolic bands are slightly shifted with respect to the PVI spectrum, and this is due to hydrogen bonding between silanol moieties and imidazole units. These are only hydrogen bonds; as in the case of protonation of PVI in the solid state, large changes in the IR spectra must happen. ${ }^{65}$ The silanol band shifts from $960 \mathrm{~cm}^{-1}$ in PSA to

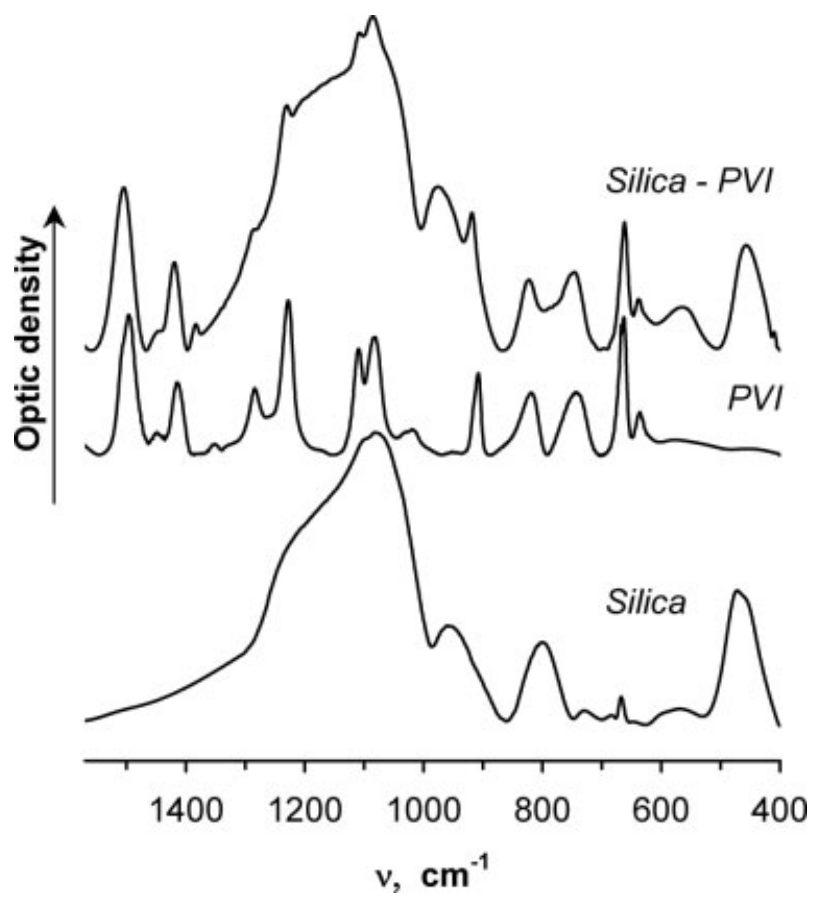

Figure 5. FTIR spectra of PVI, PSA, and a PVIPSA composite. 


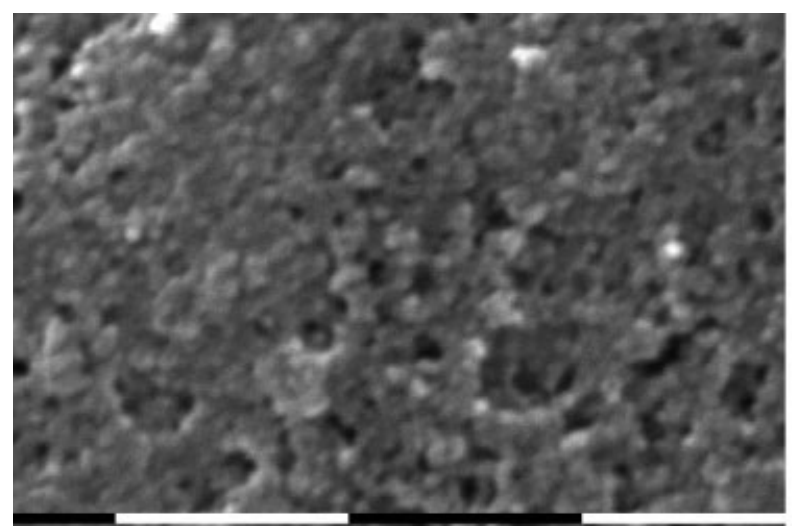

A

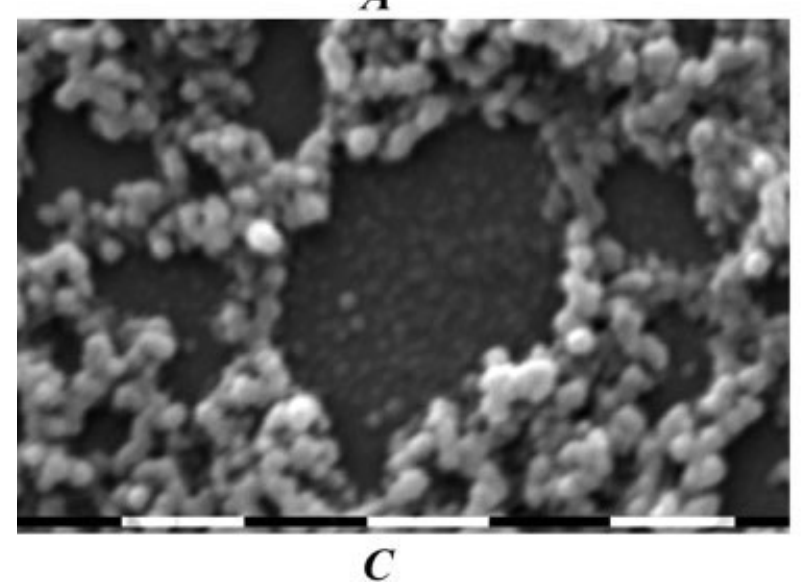

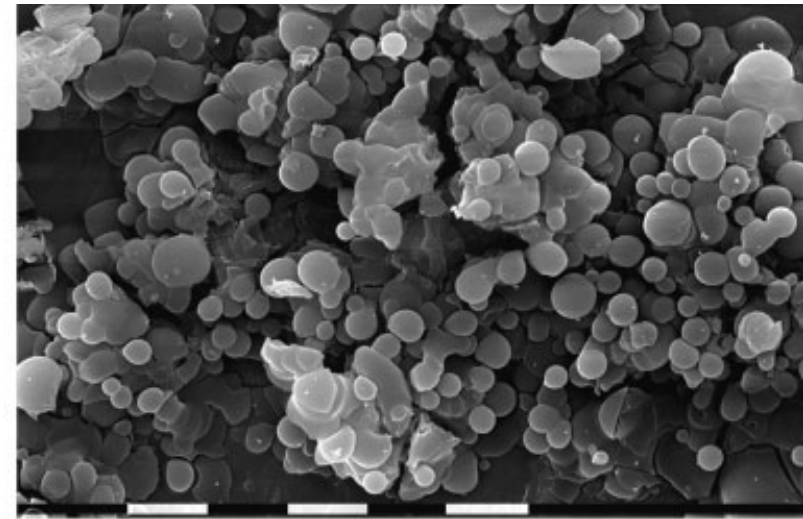

B

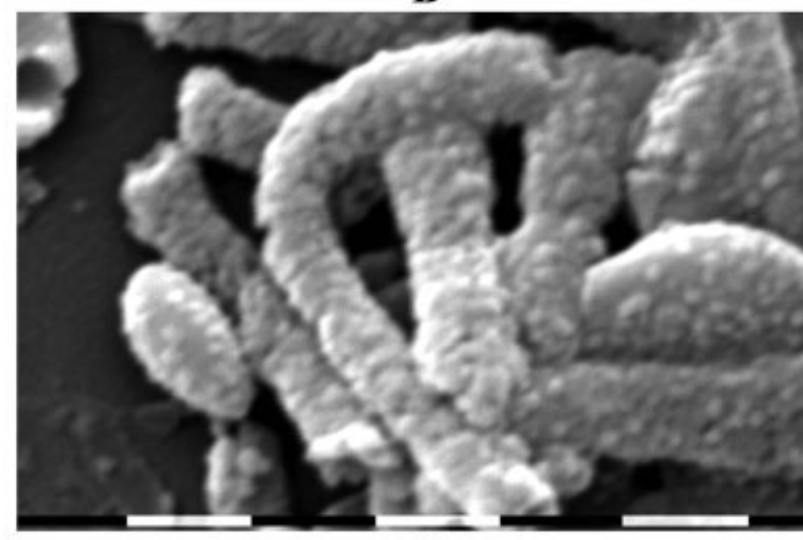

D

Figure 6. SEM data: (A) a composite obtained by the addition of PSA to a PVI solution, (B,C) particles formed during the neutralization of $\mathrm{Na}_{2} \mathrm{SiO}_{3}$ in the presence of PVI in equimolar concentrations (0.05 and $0.01 \mathrm{M}$, respectively), and (D) precipitated particles from a PVI-Na $\mathrm{SiO}_{3}$ mixture (1:1.4) after neutralization under vigorous stirring. The scale bars represent (A,C,D) 1 and (B) $10 \mu \mathrm{m}$.

$974 \mathrm{~cm}^{-1}$ in the spectrum of the composite, and this is also explained by hydrogen bonds. The optical density of the $\mathrm{Si}-\mathrm{OH}$ band increases in the spectrum of the composite (with respect to the $\mathrm{Si}-\mathrm{O}$ band at $470 \mathrm{~cm}^{-1}$ ) in comparison with solid PSA obtained under similar conditions. The condensation of silicic acid in the presence of a donating polymer probably promotes the formation of more linear products with a higher content of silanol moieties.

According to SEM data (Fig. 6), the structure of the composite precipitates depends on the method of their synthesis. The addition of previously neutralized $\mathrm{Na}_{2} \mathrm{SiO}_{3}$ to a PVI solution gives rise to aggregated particles with a size less than $100 \mathrm{~nm}$ [Fig. 6(A)], which corresponds to the presence of one PVI macromolecule in the composite particle. Evidently, the reaction of primary PSA particles with polymeric chains results in fast crosslinking and precipitation.
The neutralization of $\mathrm{Na}_{2} \mathrm{SiO}_{3}$ in the presence of PVI in an equimolar ratio at high initial concentration $(0.05 \mathrm{M})$ leads to the formation of 2 $4-\mu \mathrm{m}$ spherical particles [Fig. 6(B)]. In case of lower concentrations, the precipitate is formed only the next day, consisting of smaller particles [Fig. 6(C)]. As mentioned previously, under these conditions, the PVI reaction with silicic acid is likely to give mainly linear products, which can aggregate to large particles at high initial concentrations. The aggregation slows at lower concentrations, and the transformation of PVI-PSA complexes takes place with the formation of a three-dimensional polysiloxane net. The precipitate contains submicrometer particles [Fig. 6(C)]. The PVI-Na $\mathrm{NiO}_{3}$ system with a silicate excess occupies an intermediate state: its neutralization under stirring conditions causes a precipitate consisting of bars and large particles of irregular elongated, ellipsoidal, or cylindrical 
shapes, the surface of which is sometimes covered with submicrometer granules [Fig. 6(D)]. Large particles are probably formed from relatively linear PVI-PSA complexes as in the case of an equimolar composition. However, the high rate of condensation and precipitation stabilizes nonequilibrium elongated structures connected with vigorous stirring of the solution. Submicrometer granules on the surface of large particles are formed because of the condensation of PSA excess.

\section{CONCLUSIONS}

The interaction of a weak organic polybase with silicic acid proceeds as a set of parallel reactions: condensation in a solution giving rise to PSA nanoparticles and their interaction with the polymer and the condensation of silicic acid on the organic matrix, causing the formation of soluble products able to further aggregate. The prevalent way of the process depends not only on the component ratio, concentration, and $\mathrm{pH}$ but also on the order of reagent mixing: the presence of PVI macromolecules during silicic acid formation stabilizes soluble complexes, which precipitate in an excess of $\mathrm{H}_{4} \mathrm{SiO}_{4}$ only. The morphology of PVI-PSA composite precipitates depends on the nature of the primary particles. Therefore, the interaction of previously formed PSA with organic macromolecules results in aggregated nanoparticles less than $100 \mathrm{~nm}$ in diameter. On the other hand, the neutralization of $\mathrm{Na}_{2} \mathrm{SiO}_{3}$ in the presence of PVI is accompanied by relatively slow precipitation with larger particles.

The authors are very thankful to M. A. Grachev, a member of the Russian Academy of Sciences, for target setting and fruitful discussion of the results. They also thank the Presidium of the Russian Academy of Sciences for its financial support (projects 10.3 and 25.5).

\section{REFERENCES AND NOTES}

1. Sertchook, H.; Avnir, D. Chem Mater 2003, 15, 1690-1694.

2. Zhang, G.; Yu, Y.; Chen, X.; Han, Y.; Di, Y.; Yang, B.; Xiao, F. S.; Shen, J. C. J Colloid Interface Sci 2003, 263, 467-472.

3. Titirici, M. M.; Sellergren, B. Anal Bioanal Chem 2004, 378, 1913-1921.

4. Suzhu, Y. U.; Terence, K. S.; Wong, X. J Sol-Gel Sci Technol 2004, 29, 57-62.
5. Kim, S.-H.; Kim, Y.-W.; Park, C. B. J Mater Sci 2004, 39, 3513-3515.

6. Yachi, A.; Takahashi, R.; Sato, S.; Sodesawa, T.; Oguma, K.; Matsutani, K.; Mikami, N. J NonCryst Solids 2005, 351, 331-339.

7. Kickelbick, G. Prog Polym Sci 2003, 28, 83-114.

8. Drum, R. W.; Gordon, R. Trends Biotechnol 2003, 21, 325-328.

9. Moussaif, N.; Groeninckx, G. Polymer 2003, 44, 7899-7906.

10. Chiu, Y. S.; Wu, K. H.; Chang, T. C. Eur Polym J 2003, 39, 2253-2259.

11. Yena, C.-T.; Chena, W.-C.; Liawc, D.-J.; Lu, H.-Y. Polymer 2003, 44, 7079-7085.

12. Mori, Y.; Saito, R. Polymer 2004, 45, 95-100.

13. Percy, M. J.; Michailidou, V.; Armes, S. P.; Perruchot, C. W.; Greaves, J. F. Langmuir 2003, 19, 2072-2079.

14. Meyer, T.; Spange, S.; Hesse, S.; Jager, C.; Bellmann, C. Macromol Chem Phys 2003, 204, 725-732.

15. Cheung, I. W.; Chin, K. B.; Greene, E. R.; Smart, M. C.; Abbrent, S.; Greenbaum, S. G.; Prakash, G. K. S.; Surampudi, S. Electrochim Acta 2003, 48, 2149-2156.

16. McCool, B. A.; Cashon, R.; Karles, G.; DeSisto, W. J. J Non-Cryst Solids 2004, 333, 143-149.

17. Kotoky, T.; Dolui, S. K. J Sol-Gel Sci Technol 2004, 29, 107-114.

18. Liu, P.; Liu, W. M.; Xue, Q. J. J Mater Sci 2004, 39, 3825-3827.

19. Park, S. H.; Yan, H.; Reif, J. H.; Bean, T.; Finkelstein, G. Nanotechnology 2004, 15, 525-527.

20. Jung, H. Y.; Gupta, R. K.; Oh, Kim, E. O.; Whang, C. M. J Non-Cryst Solids 2005, 351, 372-379.

21. Lina, M.; Chua, F.; Guyotb, A.; Putauxc, J.-L.; Bourgeat-Lami, E. Polymer 2005, 46, 1331-1337.

22. Huanga, S.-L.; Chinb, W.-K.; Yang, W. P. Polymer 2005, 46, 1865-1877.

23. Trevors, J. T. Antonie van Leeuwenhoek 1997, 71, 271-276.

24. Naik, R. R.; Brott, L. L.; Clarson, S. J.; Stone, M. O. J Nanosci Nanotechnol 2002, 2, 95-100.

25. Naik, R. R.; Whitlock, P. W.; Rodriguez, F.; Brott, L. L.; Glawe, D. D.; Clarson, S. J.; Stone, M. O. Chem Commun 2003, 238-239.

26. Cha, J. N.; Shimizu, K.; Zhou, Y.; Christiansen, S. C.; Chmelka, B. F.; Stucky, G. D.; Morse, D. E. Proc Natl Acad Sci USA 1999, 96, 361-365.

27. Perry, C. C.; Keeling-Tucker, T. J Biol Inorg Chem 2000, 5, 537-550.

28. Vrieling, E. G.; Beelen, T. P. M.; van Santen, R. A.; Gieskes, W. W. C. J Biotechnol 1999, 70, 39-51.

29. Kroger, N.; Deutzmann, R.; Bergsdorf, C.; Sumper, M. Proc Natl Acad Sci 2000, 97, 14133-14138.

30. Clarson, S. J.; Whitlock, P. W.; Patwardhan, S. V.; Brot, L. L.; Naik, R. R.; Stone, M. O. Polym Mater Sci Eng 2002, 86, 81.

31. Poulsen, N.; Sumper, M.; Kroger, N. Proc Natl Acad Sci 2003, 100, 12075-12080. 
32. Kubicki, J. D.; Heaney, P. J. Geochim Cosmochim Acta 2003, 67, 4113-4121.

33. Patwardhan, S. V.; Mukherjee, N.; SteinitzKannan, M.; Clarson, S. J. Chem Commun 2003, 1122-1123.

34. Hildebrand, M. Prog Org Coat 2003, 47, 256-266.

35. Kroger, N.; Lorenz, S.; Brunner, E.; Sumper, M. Science 2002, 298, 584-586.

36. Patwardhan, S. V.; Clarson, S. J. J Inorg Organomet Polym 2003, 13, 49-53.

37. Perry, C. C. Miner Geochem 2003, 54, 291-327.

38. Perry, C. C.; Keeling-Tucker, T. Colloid Polym Sci 2003, 281, 652-664.

39. Poulsen, N.; Kroger, N. J Biol Chem 2004, 279, 42993-42999.

40. Sumper, M.; Kroger, N. J Mater Chem 2004, 14, 2059-2065.

41. Brinker, C. J.; Scherer, G. W. Sol-Gel Science: The Physics and Chemistry of Sol-Gel Processing; Academic: London, 1990; p 908.

42. Ermakova, L. N.; Nyss, P. V.; Kasaikin, V. A.; Zezin, A. B.; Kabanov, V. A. Vysokomol Soedin A 1983, 25, 1391-1399.

43. Kasaikin, V. A.; Pavlova, N. V.; Ermakova, L. N.; Zezin, A. B.; Kabanov, V. A. Colloid J 1986, 48, 452-460.

44. Kaluzhnaya, R. I.; Xylchaev, X. X.; Kasaikin, V. A.; Zezin, A. B.; Kabanov, V. A. Vysokomol Soedin 1994, 36, 257-263.

45. Habsuda, J.; Simon, G. P.; Cheng, Y.-B.; Hewitt, D. G.; Toh, H.; Diggins, D. G. J Polym Sci Part A: Polym Chem 2001, 39, 1342-1352.

46. Habsuda, J.; Simon, G. P.; Cheng, Y.-B.; Hewitt, D. G.; Diggins, D. G.; Toh Ferenc, H. Cser Polym 2002, 43, 4627-4638.

47. Averochkina, I. A.; Papicov, I. M.; Matvienko, V. N. Vysokomol Soedin A 1993, 35, 1986-1990.

48. Naik, R. R.; Whitlock, P. W.; Rodriguez, F.; Brott, L. L.; Glawe, D. D.; Clarson, S. J.; Stone, M. O. Chem Commun 2003, 2, 238-239.

49. Baranovsky, V. Y.; Suchishvili, S. A.; Kasaikin, V. A.; Kabanov, V. A. Eur Polym J 1993, 29, 111-114.
50. Papisov, I. M.; Bolyachevskaya, K. I.; Litmanovich, A. A.; Matveenko, V. N.; Volchkova, I. L. Eur Polym J 1999, 35, 2087-2094.

51. Perry, C. C.; Keeling-Tucker, T. J Chem Soc Chem Commun 1998, 2587-2588.

52. Swift, D. M.; Wheeler, A. P. J Phycol 1992, 28, 202-209.

53. Perry, C. C.; Keeling-Tucker, T. Colloid Polym Sci 2003, 281, 652-664.

54. Belton, D.; Paine, G.; Patwardhan, S.; Perry, C. C. J Mater Chem 2004, 14, 2231-2241.

55. Mazyar, N. L.; Annenkov, V. V.; Kruglova, V. A.; Ananiev, S. M.; Danilovtseva, E. N.; Rokhin, A. V.; Zinchenko, S. V. Russ Chem Bull Int Ed 2000, 49, 2013-2017.

56. Mazyar, N. L.; Annenkov, V. V.; Kruglova, V. A.; Toriachinova, D. C. D.; Danilovtseva, E. N. Vysokomol Soedin A 1999, 41, 357-362.

57. Annenkov, V. V.; Filina, E. A.; Danilovtseva, E. N.; Zinchenko, S. V.; Michaleva, A. I. J Sol-Gel Sci Technol 2003, 27, 163-166.

58. Pekel, N.; Guven, O. Colloid Polym Sci 1999, 277, 570-573.

59. Kariakin, Y. V.; Angelov, I. I. Pure Chemical Substances; Chemistry: Moscow, 1974; p 408.

60. Iler, R. K. The Chemistry of Silica: Solubility, Polymerization, Colloid and Surface Property and Biochemistry; Wiley: New York, 1979.

61. Ignatyev, I. S.; Partal, F.; Gonzalez, J. J. L. Chem Phys Lett 2003, 368, 616-624.

62. Cypryk, M.; Apeloig, Y. Organometallics 2002, 21, 2165-2175.

63. Shimizu, K.; Del Amo, Y.; Brzezinski, M. A.; Stucky, G. D.; Morse, D. E. Chem Biol 2001, 8, 1051-1060.

64. Vrieling, E. G.; Gieskes, W. W. C. J Phycol 1999, $35,548-559$.

65. Lippert, J. L.; Robertson, J. A.;. Havens, J. R.; Tan, J. S. Macromolecules 1985, 18, 63-67.

66. Adeogun, M. J.; Hay, J. N. J Sol-Gel Sci Technol 2001, 20, 119-128. 